\title{
Quantification of Bacterial Attachment-related Parameters in Porous Media
}

\author{
Seong-Jik Park, Chang-Gu Lee, and Song-Bae Kim ${ }^{\dagger}$ \\ Environmental Biocolloid Engineering Laboratory, Program in Rural System Engineering, Seoul National University, Seoul 151-921, Korea
}

Received April 2008, accepted May 2008

\begin{abstract}
Transport of Escherichia coli ATCC 11105 through porous media was investigated in this study using two sets of column experiments to quantify the attachment-related parameters (sticking efficiency, attachment rate coefficient and filter factor). The first set of experiments was performed in quartz sand under different ionic strength conditions $(1,20,100,200 \mathrm{mM})$ while the second experiments were carried out in quartz sand mixed with metal oxyhydroxide-coated sand $(0,5,10,25 \%)$. The breakthrough curves of bacteria were obtained by monitoring effluent, and then bacterial mass recovery and attachment-related parameters were quantified from these curves. The first experiments showed that the mass recoveries were in the range of 13.3 to $64.7 \%$, decreasing with increasing ionic strength. In the second experiments, the mass recoveries were in the range of 15.0 to $43.4 \%$, decreasing with increasing coated sand content. The analysis indicated that the sticking efficiency, attachment rate coefficient and filter factor increased with increasing ionic strength and coated sand content. The value of filter factor in the first experiments ranged from 1.45 e- 2 to 6.72 e- 2 $1 / \mathrm{cm}$ while in the second experiments it ranged from 2.78 e- 2 to 6.32 e- $21 / \mathrm{cm}$. Our filter factor values are one order of magnitude lower than those from other studies. This discrepancy can be attributed to the size of sand used in the experiment. The analysis demonstrated that the travel distance of bacteria estimated using the filter factor can be varied greatly depending on the solution chemistry and charge heterogeneity of porous media.
\end{abstract}

Keywords: Bacterial transport, Sticking efficiency, Attachment rate coefficient, Filter factor, Travel distance

\section{Introduction}

Microbial contamination of groundwater resources is a widespread environmental problem, deteriorating drinking water quality and posing a great threat to human health. ${ }^{1,2)}$ Thus, an understanding of bacterial transport in porous media is important in the protection of groundwater. Escherichia coli is widely used as an indicator organism for bacterial contamination of water resources. Several researchers have investigated attachment and transport of $E$. coli in porous media. These studies have looked at the transport of $E$. coli through saturated soil in field experiments, ${ }^{3)}$ transport of E. coli K-12 through columns packed with silt loam and silty clay loam, ${ }^{4)}$ movement of $E$. coli NAR through unsaturated soil columns with macropores, ${ }^{5}$ removal of $E$. coli ATCC 13607 in columns containing metal hydroxides coated sands, ${ }^{6)}$ adhesion of E. coli HCB437 and HCB137 to surface-modified quartz surfaces, ${ }^{7}$ transport of E. coli ATCC 25922 through columns packed with quartz sand ${ }^{8)}$ and with various contents of goethite-coated sand, ${ }^{9)}$ and transport of $E$. coli JM109 in soil aquifer treatment system. ${ }^{10)}$ However, more

\footnotetext{
${ }^{\dagger}$ Corresponding author

E-mail: songbkim@snu.ac.kr

Tel: +82-2-880-4587, Fax: +82-2-873-2087
}

quantitative approach is required in order to improve our knowledge regarding the bacteria transport in porous media and to protect the groundwater from microbial contamination.

In this study, bacterial transport through porous media was investigated using column experiments to quantify the attachment-related parameters. The first set of the experiments was performed in quartz sand under different ionic strength conditions while the second experiments were carried out under different mixtures of quartz and metal oxyhydroxide-coated sands. Bacterial breakthrough curves were obtained by monitoring effluent, and then bacterial mass recovery and attachment-related parameters were quantified from these curves.

\section{Theory}

In porous media, the bacterial movement is mainly controlled by advective-dispersive transport and adhesion to solid matrices. ${ }^{11)}$ The bacterial attachment to a solid matrix is influenced by solution chemistry (e.g., ionic strength and $\mathrm{pH}$ ), properties of porous media (e.g., surface charge and grain size), and characteristics of bacteria (e.g., cell geometry and surface property). ${ }^{12,13)}$ The one-dimensional bacteria transport in saturated porous media can be described as: 


$$
\frac{\partial C}{\partial t}=D \frac{\partial^{2} C}{\partial x^{2}}-v \frac{\partial C}{\partial x}-k_{a} C
$$

where $C$ is the bacterial concentration in the aqueous phase, $D$ is the hydrodynamic dispersion coefficient, $v$ is the porewater velocity, and $k_{a}$ is the attachment rate coefficient $\left(\mathrm{T}^{-1}\right)$. Note that bacterial growth and decay are assumed to be negligible. According to colloid filtration theory, the attachment rate coefficient $\left(k_{a}\right)$ can be described by the following equation: ${ }^{14)}$

$$
k_{a}=\frac{3}{2} \frac{(1-n)}{d_{c}} v \eta \alpha ; \quad v=\frac{U}{n}
$$

where $n$ is the porosity, $d_{c}$ is the particle diameter of porous media, $\eta$ is the collision efficiency, $\alpha$ is the sticking efficiency, and $U$ is the flow approach velocity (= Darcy velocity).

The collision efficiency $(\eta)$ can be calculated using the following equation: ${ }^{15)}$

$\eta=2.4 A_{S}^{1 / 3} N_{R}^{-0.081} N_{P e}^{-0.715} N_{v d W}^{0.052}+0.55 A_{S} N_{R}^{1.675} N_{A}^{0.125}+0.22 N_{R}^{-0.24} N_{G}^{1.11} N_{v d W}^{0.053}$

where $A_{S}$ is the porosity - dependent parameter, $N_{R}$ is the aspect ratio, $N_{P e}$ is the Peclet number, $N_{v d W}$ is the van der Waals number, $N_{A}$ is the attraction number, and $N_{G}$ is the gravity number. The parameters used in the calculation of $\eta$ are summarized in Table 1 . The sticking efficiency $(\alpha)$ can be determined with the following equation: ${ }^{15)}$

Table 1. Parameters used for collision efficiency (n) of Escherichia coli in sand

\begin{tabular}{lcc}
\hline Parameter & Unit & Value \\
\hline Column length & $\mathrm{cm}$ & 30 \\
Particle diameter of sand & $\mathrm{mm}$ & 1.0 \\
Particle diameter of bacteria $^{*}$ & $\mu \mathrm{m}$ & 1.21 \\
Particle density of bacteria $^{*}$ & $\mathrm{~g} / \mathrm{cm}^{3}$ & 1.105 \\
Fluid absolute temperature & $\mathrm{K}$ & 298 \\
Fluid density & $\mathrm{g} / \mathrm{cm}^{3}$ & 0.997 \\
Fluid viscosity & $\mathrm{g} / \mathrm{cm}^{3} \mathrm{~s}$ & $8.91 \times 10^{-3}$ \\
Hamaker constant & $\mathrm{J}$ & $6.5 \times 10^{-21}$ \\
Boltzman constant & $\mathrm{J} / \mathrm{K}$ & $1.38 \times 10^{-23}$ \\
Bulk diffusion coefficient & $\mathrm{cm}^{2} / \mathrm{sec}$ & $4.05 \times 10^{-9}$ \\
\hline
\end{tabular}

*Particle density of bacteria was from Martínez-Salas ${ }^{23)}$

$$
\alpha=-\frac{2}{3} \frac{d_{c}}{(1-n) L \eta} \ln (M r)
$$

where $L$ is the column length, and $M r$ is the bacterial mass recovery in the effluent, which can be quantified by the following relationship:

$$
M r=\left(\frac{\int_{0}^{\infty} C d t}{C_{0} t_{0}}\right)
$$

where $C_{0}$ is the initial concentration of bacteria, and $t_{0}$ is the duration of bacteria injection (injection time).

The attachment rate coefficient $\left(k_{a}\right)$ has the following relationship with the filter factor $\left(f, \mathrm{~L}^{-1}\right):^{14)}$

$$
f=\frac{k_{a}}{v}
$$

Thus, $f$ can be expressed in terms of mass recovery $\left(M_{r}\right)$ by incorporating Equations (2) and (4) into Equation (6) as: ${ }^{16)}$

$$
f=-\frac{1}{L} \ln (M r)=-\frac{2.3025}{L} \log _{10}(M r)
$$

From the Equation (7), the relationship between log removal and travel distance $\left(T_{d}\right)$ of bacteria can be described as:

$$
T_{d}=\frac{2.3025}{f} *(\log \text { removal })
$$

where the log removal denotes - $\log _{10}(\mathrm{Mr})$. For instance, $99 \%$ of bacterial removal is equal to 2 log removal.

\section{Materials and Methods}

\subsection{Bacteria and Culture Preparation}

E. coli ATCC 11105 obtained from the Korea Culture Center for Microorganisms was used in this experiment. All glassware and materials used in this study were sterilized by autoclaving at $121^{\circ} \mathrm{C}$ and $17.6 \mathrm{psi}$ for $20 \mathrm{~min}$ to prevent any interference by other microorganisms. Initially, the freeze-dried bacteria were revived in 250-mL Erlenmeyer flasks containing $100 \mathrm{~mL}$ of LB medium (tryptone $10 \mathrm{~g}$, yeast extract $5 \mathrm{~g}, \mathrm{NaCl} 5 \mathrm{~g}$ in one liter of deionized water at $\mathrm{pH} 7.0$ ) over a period of $84 \mathrm{~h}$. Then one milliliter of culture was transferred to a volume of $500 \mathrm{~mL} \mathrm{LB}$ broth, and the bacteria were incubated over a period of $84 \mathrm{~h}$ at $30^{\circ} \mathrm{C}$. The suspension was centrifuged at $4^{\circ} \mathrm{C}$ and $10,000 \mathrm{rpm}$ for $15 \mathrm{~min}$. The supernatant was removed and replaced with deionized water to prevent growth of the bacteria. Then the diluted bacteria were centrifuged again under the same conditions. The centrifuged bacteria were washed three times with deionized water and resuspended in deionized water to an optical density of 0.5 at $600 \mathrm{~nm}\left(\mathrm{OD}_{600}\right)$. Transmission electron microscopy (JEM 1010, JEOL, Japan) was used to take images of $E$. coli cells. The images were imported into an image-processing program (Image-Pro Plus) and analyzed. The average length and diameter of E. coli were $2.2 \mu \mathrm{m}$ and $0.6 \mu \mathrm{m}$, respectively, which corresponded to an equivalent spherical diameter of 1.21 $\mu \mathrm{m}$. The net surface electrostatic characteristics of cells were analyzed with an Electrophoretic Light Scattering Spectrophotometer (ELS-8000, Otsuka Electronics, Japan). Electrophoretic mobility was determined for the bacterial surface $(\mathrm{pH}=6.8$, temp. $=25^{\circ} \mathrm{C}$, ionic strength $\approx 0 \mathrm{mM}$ ) and converted to zeta 
potentials using the Smoluchowski equation. The zeta potential of $E$. coli was determined to be $-51 \pm 6 \mathrm{mV}$.

\subsection{Porous Media}

Quartz sand (effective size: $1.0 \mathrm{~mm}$, uniformity coefficient: 1.53) supplied by Jumunjin Silica was used in the experiments. Before use, sand was washed twice using deionized water to remove impurities on the surface, and wet sand was autoclaved for $20 \mathrm{~min}$ at $17.6 \mathrm{psi}$, cooled to room temperature, and ovendried at $105^{\circ} \mathrm{C}$ for $1-2$ days. For the preparation of Al-coated sand, $\mathrm{AlCl}_{3} \cdot 6 \mathrm{H}_{2} \mathrm{O}$ (4.9 g) was dissolved in deionized water $(100 \mathrm{~mL})$, and the solution $\mathrm{pH}$ was adjusted to $\mathrm{pH} 7.0$ with $6 \mathrm{~N}$ $\mathrm{NaOH}$. The quartz sand (200 g) was added to the $\mathrm{AlCl}_{3} \cdot 6 \mathrm{H}_{2} \mathrm{O}$ solution and then mixed in a rotary evaporator (HAHNVAPOR, Hahnshin Scientific Co., Korea) to remove water in the suspension by heating $\left(90^{\circ} \mathrm{C}, 80 \mathrm{rpm}, 20 \mathrm{~min}\right)$. The same procedure used for Al-coated sand was applied using $\mathrm{FeCl}_{3} \cdot 6 \mathrm{H}_{2} \mathrm{O}(5.5 \mathrm{~g})$ for Fe-coated sand. The coated sand was dried in a drying oven (J-NDS2, JISICO, Korea) at $150^{\circ} \mathrm{C}$ for $6 \mathrm{hr}$, washed with deionized water and then dried again at the same conditions.

\subsection{Column Experiments}

Two sets of column experiments were performed using a Plexiglas column (length $=30 \mathrm{~cm}$; inner diameter $=2.5 \mathrm{~cm}$ ) under the leaching solution prepared with $\mathrm{NaCl}$ and phosphate $\left(\mathrm{KH}_{2} \mathrm{PO}_{4}\right.$, $\mathrm{K}_{2} \mathrm{HPO}_{4}$ ). The experimental conditions were summarized in Table 2. The first set of experiments (1a-1d) was conducted in quartz sand at different ionic strength (IS) conditions (1, 20, 100, $200 \mathrm{mM}$ ). A column was packed for each experiment by the tap-fill method to attain a bulk density of $1.583 \pm 0.002 \mathrm{~g} / \mathrm{cm}^{3}$ and a porosity of $0.403 \pm 0.001$. The column was connected to a pump (QG400, FASCO, USA) operating at a rate of $0.5 \mathrm{~mL} /$ min. Prior to the experiments, the packed column was flushed upward with 8-10 pore volumes of the leaching solution until the column effluents were clear and a steady state flow condition was established. The column experiment was performed by injecting bacteria solution of $0.5 \mathrm{OD}_{600}$ downward for $60 \mathrm{~min}$. After completing injection of the tracer, leaching solution was introduced again. Effluent samples were collected using an auto collector (Retriever 500, TELEDYNE, USA) at a regular interval and analyzed for bacterial concentration along with $\mathrm{pH}$ and
EC. Bacterial concentration was determined by measuring the optical density of the effluent using a UV-visible spectrophotometer (Helios, Thermo, USA) at $600 \mathrm{~nm}\left(\mathrm{OD}_{600}\right), \mathrm{pH}$ with a $\mathrm{pH}$ probe (9107BN, Orion, USA), and EC with an EC probe (815PDL, Istek, Korea). The second set of experiments (2a-2d) was performed (flow rate $=0.35 \mathrm{~mL} / \mathrm{min}$ ) in quartz sand mixed with metal oxyhydroxide-coated sand $(0,5,10,25 \%)$ under the ionic strength of $5.3 \mathrm{mM}$. The second experiments used the same procedure as the first. The bulk density and porosity of columns were $1.580 \pm 0.002 \mathrm{~g} / \mathrm{cm}^{3}$ and $0.403 \pm 0.001$, respectively.

\section{Results and Discussion}

\subsection{Bacterial Mass Recovery}

The bacterial breakthrough curves (BTCs) obtained from the first experiments (1a-1d) are presented in Fig. 1. The bacterial mass recoveries in the first experiments were in the range of 13.3 to $64.7 \%$, decreasing with increasing ionic strength (IS). In quartz sand, the mass recovery was $64.7 \%$ at IS $=1 \mathrm{mM}$ (1a), decreasing to $50.5 \%$ with increasing IS to $20 \mathrm{mM}$ (1b). When IS increased further to 100 and $200 \mathrm{mM}$, the mass recoveries decreased to 20.2 and $13.3 \%$ (1c, 1d), respectively. Our result is comparable with the studies of other researchers who have examined the decreasing bacterial mass recovery with increasing IS in quartz sand. ${ }^{17,18)}$ This phenomenon can be explained by the DLVO theory. Because the surface charges of both quartz sand and bacteria are negative at circumneutral $\mathrm{pH}^{19)}$ increas-

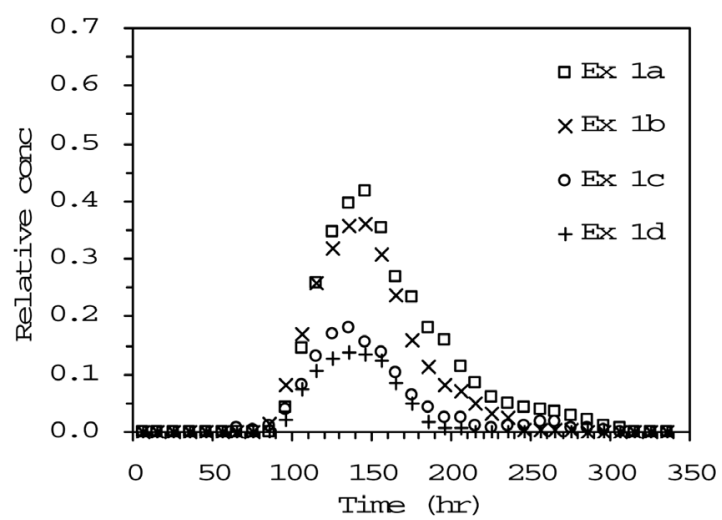

Fig. 1. Breakthrough curves of Escherichia coli in quartz sand at various ionic strength conditions.

Table 2. Experimental conditions for column experiments of Escherichia coli

\begin{tabular}{|c|c|c|c|c|c|c|c|c|}
\hline \multirow[t]{2}{*}{ Ex } & \multicolumn{2}{|c|}{ Media (\%) } & \multirow{2}{*}{$\begin{array}{l}\text { Bulk density } \\
\left(\mathrm{g} / \mathrm{cm}^{3}\right)\end{array}$} & \multirow[t]{2}{*}{ porosity } & \multirow{2}{*}{$\begin{array}{l}\text { Flow rate } \\
(\mathrm{mL} / \mathrm{min})\end{array}$} & \multirow[t]{2}{*}{$\mathrm{pH}$} & \multirow{2}{*}{$\begin{array}{l}\text { Is } \\
(\mathrm{mM})\end{array}$} & \multirow{2}{*}{$\begin{array}{l}\text { EC } \\
(\mu \mathrm{S} / \mathrm{cm})\end{array}$} \\
\hline & $\begin{array}{l}\text { quartz } \\
\text {. }\end{array}$ & coated & & & & & & \\
\hline $1 \mathrm{a}$ & 100 & 0 & 1.586 & 0.402 & 0.50 & 7.3 & 1 & 91 \\
\hline $1 c$ & 100 & 0 & 1.582 & 0.403 & 0.50 & 7.2 & 100 & 9,856 \\
\hline $1 d$ & 100 & 0 & 1.581 & 0.403 & 0.50 & 7.3 & 200 & 19,073 \\
\hline $2 a$ & 100 & 0 & 1.582 & 0.403 & 0.35 & 7.5 & 5.3 & 539 \\
\hline $2 c$ & 90 & 10 & 1.581 & 0.403 & 0.35 & 7.6 & 5.3 & 538 \\
\hline $2 \mathrm{~d}$ & 75 & 25 & 1.577 & 0.405 & 0.35 & 7.7 & 5.3 & 548 \\
\hline
\end{tabular}




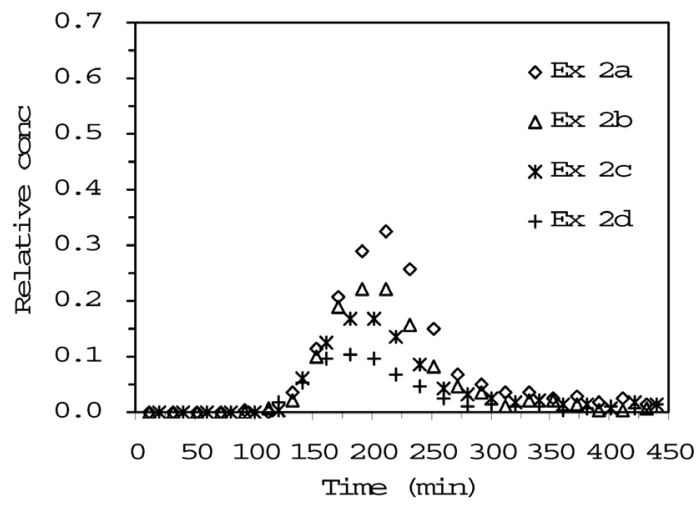

Fig. 2. Breakthrough curves of Escherichia coli in quartz sand mixed with metal oxyhydroxide-coated sand.

ing IS of leaching solution leads to a decrease in the thickness of the electrical double layers and in the average distance between both surfaces, resulting in the enhancement of bacterial adhesion to the surfaces of quartz sand.

The BTCs from the second experiments (2a-2d) are presented in Fig. 2. In the second experiments, the mass recoveries ranged from 15.0 to $43.4 \%$, decreasing with increasing coated sand content in mixed media. The mass recovery in quartz sand (2a) was $43.4 \%$, which was lower than that of 1a (64.7\%). This can be attributed to the fact that the column experiment in 2a was conducted at lower flow rate and higher IS than 1a (Table 1). As the coated sand content increased from 5 to $25 \%$ (2b-2d), the mass recoveries decreased from 30.1 to $15.0 \%$. Our results are consistent with the work of other researchers ${ }^{9)}$ who have shown that the mass recovery of $E$. coli decreased with increasing goethite-coated sand content in column experiment. It is well known that the metal (Fe, $\mathrm{Al}$ ) oxyhydroxides carry positive surface charges at circumneutral $\mathrm{pH}$ conditions. Therefore, negatively-charged bacteria can favorably adhere to the positivelycharged surfaces of porous media.

\subsection{Attachment-Related Parameters}

In the first experiments (1a-1d), the sticking efficiencies $(\alpha)$ were in the range of 0.149 to 0.694 , increasing with increasing IS in quartz sand. The value of $\alpha$ in the second experiments (2a-2d) increased from 0.213 to 0.484 with increasing coated sand content from 0 to $25 \%$ in mixed media. In colloid filtration theory, the removal of colloid by attachment to a collector (e.g. sand) can be described by collector efficiency $(C=\eta \alpha)$, which denotes the probability that a colloidal particle approaching a collector both collides with and sticks to the collector. ${ }^{19)}$ The collision efficiency $(\eta)$ is the probability that a colloidal particle approaching a collector collides with the collector while the sticking efficiency $(\alpha)$ is the probability that the particle colliding with the collector sticks to that collector. Our result indicates that the collision efficiency of E. coli in quartz sand increases with increasing IS and coated sand content, resulting in the enhancement of bacteria removal.

The attachment rate coefficient $\left(k_{a}\right)$ in the first experiments (1a-1d) ranged from 3.68 e-3 to 1.70 e-2 1/min, increasing with increasing IS in quartz sand. In the second experiments (2a-2d), the value of $k_{a}$ ranged from 4.92 e-3 to $1.11 \mathrm{e}-21 / \mathrm{min}$, increasing with increasing coated sand content in mixed media. The attachment rate coefficient is the temporal coefficient, which can be converted to the spatial coefficient (filter factor) using Equation (6). As presented in Equation (7), the filter factor ( $f$ ) is $\log$-linearly related to the mass recovery. The value of $f$ in the first experiments (1a-1d) increased with increasing IS in quartz sand. It ranged from 1.45 e-2 to $6.72 \mathrm{e}-21 / \mathrm{cm}$. The value of $\mathrm{f}$ in the second experiments (2a-2d) increased with increasing coated sand content. It ranged from 2.78 e-2 to $6.32 \mathrm{e}-21 / \mathrm{cm}$. Our $f$ values are one order of magnitude lower than those from other studies. The $f$ values of $E$. coli calculated from Foppen and Schijven ${ }^{9)}$ were ranged from 4.46 e-1 to 6.97 e- $11 / \mathrm{cm}$, increasing with increasing coated sand content from 0 to $20 \%$ in mixed media (sand size $=0.235 \mathrm{~mm}$ ). The $f$ value of $E$. coli determined from Bolster et al. ${ }^{21)}$ was $2.21 \mathrm{e}-11 / \mathrm{cm}$ (sand size $=0.25-0.35$ $\mathrm{mm}$ ). This discrepancy can be attributed to the size of sand used in the experiment. The grain size used in their studies was about four times larger than ours $(1.0 \mathrm{~mm})$.

\subsection{Log Removal and Travel Distance}

The travel distance $\left(T_{d}\right)$ of bacteria can be estimated with the filter factor $(f)$ determined from the experiment using Equation (8) (Fig. 3). In the estimation of $T_{d}$, the concentration of E. coli is assumed to be $10^{6} \mathrm{cfu} / 100 \mathrm{~mL}$ (cfu: colony forming unit) based on the report of Pang et al. ${ }^{22)}$ As shown in Fig. 3, the values of $f$ used in the estimation were 1.45 e-2 (1a), 6.72 e-2 (1d), 2.78 e-2 (2a), and 6.32 e-2 (2d). At $f=1.45$ e-2 (1a: quartz sand,

Table 3. Experimental results for column experiments of Escherichia coli

\begin{tabular}{lllllll}
\hline Ex & $\begin{array}{l}\mathrm{U} \\
(\mathrm{cm} / \mathrm{min})\end{array}$ & $\begin{array}{l}\mathrm{Mr} \\
(\%)\end{array}$ & $n$ & $\mathrm{a}$ & $\begin{array}{l}\mathrm{ka} \\
(1 / \mathrm{min})\end{array}$ & $\begin{array}{l}\mathrm{f} \\
(1 / \mathrm{cm})\end{array}$ \\
\hline 1a & 0.102 & 64.7 & 0.0108 & 0.149 & $3.68 \mathrm{e}-3$ & $1.45 \mathrm{e}-2$ \\
1b & 0.102 & 50.5 & 0.0108 & 0.235 & $5.76 \mathrm{e}-3$ & $2.28 \mathrm{e}-2$ \\
1c & 0.102 & 20.2 & 0.0108 & 0.550 & $1.35 \mathrm{e}-2$ & $5.33 \mathrm{e}-2$ \\
1d & 0.102 & 13.3 & 0.0108 & 0.694 & $1.70 \mathrm{e}-2$ & $6.72 \mathrm{e}-2$ \\
2a & 0.071 & 43.4 & 0.0146 & 0.213 & $7.92 \mathrm{e}-3$ & $2.78 \mathrm{e}-2$ \\
2b & 0.071 & 30.1 & 0.0146 & 0.306 & $8.30 \mathrm{e}-3$ & $4.01 \mathrm{e}-2$ \\
2c & 0.071 & 24.4 & 0.0146 & 0.360 & $1.11 \mathrm{e}-2$ & $4.70 \mathrm{e}-2$ \\
2d & 0.071 & 15.0 & 0.0146 & 0.484 & & $6.32 \mathrm{e}-2$ \\
\hline
\end{tabular}




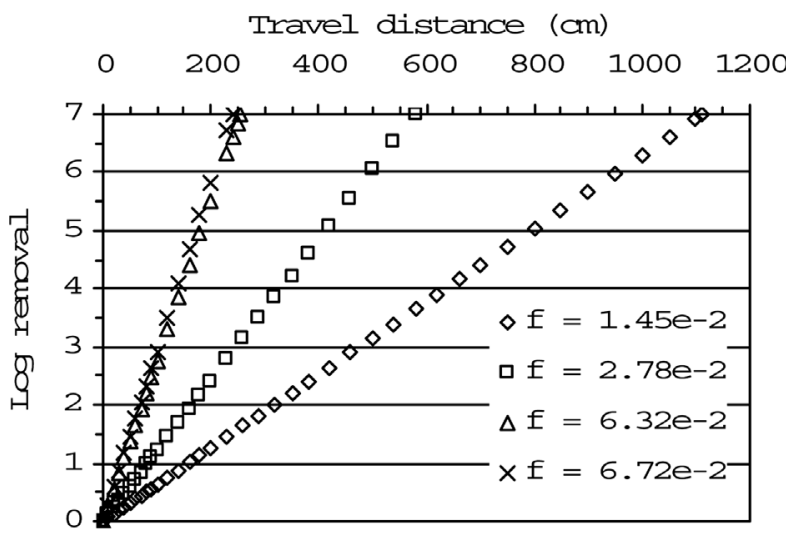

Fig. 3. Travel distance and log removal of Escherichia coli based on the laboratory-determined filter factor.

IS $=1 \mathrm{mM}), T_{d}$ of $476 \mathrm{~cm}$ is required to achieve 3-log removal (99.9\% removal) and $T_{d}$ of $1112 \mathrm{~cm}$ for 7-log removal (complete removal of $10^{6} \mathrm{cfu} / 100 \mathrm{~mL}$ ). At $6.72 \mathrm{e}-2$ (1d: quartz sand, IS $=200 \mathrm{mM}$ ), $T_{d}$ is $103 \mathrm{~cm}$ for 3-log removal and $240 \mathrm{~cm}$ for 7-log removal. This indicates that the travel distance of bacteria can be changed considerably due to solution chemistry (e.g. ionic strength). At $f=2.78$ e-2 (2a: quartz sand $100 \%$, IS $=5.3$ $\mathrm{mM}), T_{d}$ is $248 \mathrm{~cm}$ for 3-log removal and $580 \mathrm{~cm}$ for 7-log removal. At 6.72 e-2 (2d: quartz sand $75 \%$, coated sand $25 \%$, IS $=5.3 \mathrm{mM}), T_{d}$ is $109 \mathrm{~cm}$ for 3-log removal and $255 \mathrm{~cm}$ for 7-log removal. This demonstrates that the travel distance of bacteria can be reduced markedly due to the presence of positively-charged metal oxyhydroxide-coated sand. As mentioned previously, the values of $f$ determined at smaller sand size by other researchers were one order of magnitude larger than ours. Thus, it is expected that the travel distance of bacteria can be influenced greatly by particle size of porous media.

\section{Conclusions}

The attachment-related parameters for $E$. coli were quantified from column experiments in porous media. The first experiments show that the mass recovery in quartz sand decreased while the sticking efficiency increased with increasing ionic strength. In addition, the attachment rate coefficient and filter factor increased with increasing ionic strength. The second experiments indicate that the mass recovery decreased while the sticking efficiency, attachment rate coefficient and filter factor increased with increasing metal oxyhydroxide-coated sands. The analysis demonstrates that the travel distance of bacteria can be varied greatly depending on the solution chemistry and charge heterogeneity of porous media. Further research should focus on examining the influence of physical heterogeneity of porous media on the attachment-related parameters and travel distance of bacteria.

\section{References}

1. Crane, S. R., and Moore, J. A., "Bacterial pollution of groundwater: A review,” Water Air Soil Pollut., 22, 67-83 (1984).
2. Macler, B. A., and Merkle, J. C., "Current knowledge on groundwater microbial pathogens and their control," Hydrogeol. J., 8, 29-40 (2000).

3. Sinton, L. W., Noonan, M. J., Finlay, R. K., Pang, L., and Close, M. E., "Transport and attenuation of bacteria and bacteriophages in an alluvial aquifer," New Zealand $J$. Marine Freshwater Res., 34, 175-186 (2000).

4. Smith, M. S., Thomas, G. W., White, R. E., and Ritonga, D., "Transport of Escherichia coli through intact and disturbed soil columns," J. Environ. Qual., 14, 87-91 (1985).

5. Abu-Ashour, J., Joy, D. M., Lee, H., Whiteley, H. R., and Zelin, S., "Movement of bacteria in unsaturated soil columns with macropores," Transactions of the ASAE, 41, 1043-1050 (1998).

6. Lukasik, J., Cheng, Y.-F., Lu, F., Tamplin, M., and Farrah, S. R., "Removal of microorganisms from water by columns containing sand coated with ferric and aluminum hydroxides," Water Res., 33, 769-777 (1999).

7. Vigeant, M. A., Ford, R. M., Wagner, M., and Tamm, L. K., "Reversible and irreversible adhesion of motile Escherichia coli cells analyzed by total internal reflection aqueous fluorescence microscopy,” Appl. Environ. Microbiol., 68, 27942801 (2002).

8. Foppen, J. W. A., Mporokoso, A., and Schijven, J. F., “Determining straining of Escherichia coli from breakthrough curves," J. Contam. Hydrol., 76, 191-210 (2005).

9. Foppen, J. W. A., and Schijven, J. F., "Transport of E. coli in columns of geochemically heterogeneous sediment," Water Res., 39, 3082-3088 (2005).

10. Won, J., Kim, J.-W., Kang, S., and Choi, H., "Transport and adhesion of Escherichia coli JM109 in soil aquifer treatment (SAT): one-dimensional column study," Environ. Monitor. Assess., 129, 9-18 (2007).

11. Hornberger, G. M., Mills, A. L., and Herman, J. S., "Bacterial transport in porous media: evaluation of a model using laboratory observations,” Water Resour. Res., 28, 915-938 (1992).

12. Gannon, J. T., Manilal, V. B., and Alexander, M., "Relationship between cell surface properties and transport of bacteria through soil,” Appl. Environ. Microbiol., 57, 190-193 (1991).

13. Fontes, D. E., Mills, A. L., Hornberger, G. M., and Herman, J. S., "Physical and chemical factors influencing transport of microorganisms through porous media," Appl. Environ. Microbiol., 57, 2473-2481 (1991).

14. Pang, L., Close, M., Goltz, M., Noonan, M., and Sinton, L., "Filtration and transport of Bacillus subtilis spores and the F-RNA phage MS2 in a coarse alluvial gravel aquifer: Implications in the estimation of setback distances," J. Contam. Hydrol., 77, 165-194 (2005).

15. Tufenkji, N., and Elimelich, M., "Correlation equation for predicting single-collector efficiency in physicochemical filtration in saturated porous media," Environ. Sci. Technol., 38, 529-536 (2004).

16. Baik, M. H., Hahn, P. S., and Vilks, P., "Colloid migration in a fractured granite: evaluation of colloid migration para- 
meters," Environ. Eng. Res., 7, 137-148 (2002).

17. Bolster, C. H., Mills, A. L., Hornberger, G. M., and Herman, J. S., "Effect of surface coatings, grain size, and ionic strength on the maximum attainable coverage of bacteria on sand surfaces," J. Contam. Hydrol., 50, 287-305 (2001).

18. Mills, A. L., Herman, J. S., Hornberger, G. M., and DeJesus, T. H., "Effect of solution ionic strength and iron coatings on mineral grains on the sorption of bacterial cells to quartz sand,” Appl. Environ. Microbiol., 60, 3300-3306 (1994).

19. Scholl, M. A., Mills, A. L., Herman, J. S., and Hornberger, G. M., "The influence of mineralogy and solution chemistry on the attachment of bacteria to representative aquifer materials,” J. Contam. Hydrol., 6, 321-336 (1990).

20. Cail, T. L., and Hochella, Jr, M. F., "The effects of solution chemistry on the sticking efficiencies of viable Enterococcus faecalis: an atomic force microscopy and modeling study,” Geochim. Cosmochim. Acta, 69, 2959-2969 (2005).

21. Bolster, C. H., Walker, S. L., and Cook, K., "Comparison of Escherichia coli and Campylobacter jejuni transport in saturated porous media,” J. Environ. Qual., 35, 1018-1025 (2006).

22. Pang, L., Close, M., Goltz, M., Sinton, L., Davies, H, Hall, C., and Stanton, G., "Estimation of septic tank setback distances based on transport of E. coli and F-RNA phages," Environ. Int., 29, 907-921 (2003).

23. Martinez-Salas, E., Martin, J. A., Vicente, M., "Relationship of Escherichia coli density to growth rate and cell age,” J. Bacteriol., 147, 97-100 (1981). 